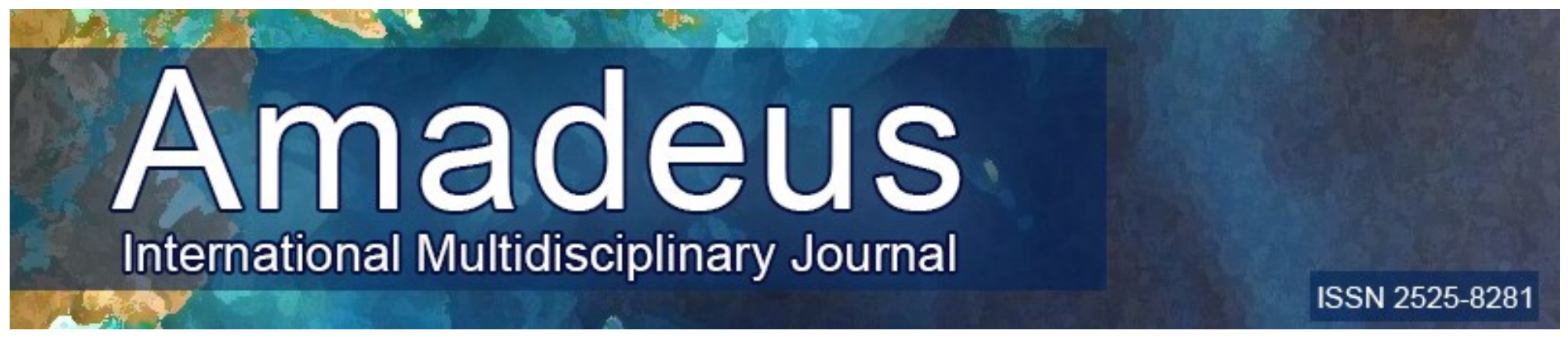

DOI: 10.14295/AIMJ.V6I11.171

\title{
Professional Perspectives of the Management Course Students - Class of 2015 of the Vale do Acaraú University - UVA/IDJ
}

\author{
Livia Dayanne Silva Nogueira ${ }^{1}$ \\ Felipe Neris Torres de Sousa ${ }^{2}$ \\ Maria Eliete da Silva Saldanha ${ }^{3}$
}

Abstract: This article aims to analyze the premises, perspectives and professional expectations of students who enter the Administration course. For this purpose, the following specific objectives were listed: characterize the public investigated as to some social and economic aspects; identify the main justifications that influenced the choice of the course of Administration and analyze the perspectives and expectations regarding the choice of the same. The study was characterized from two aspects, as well as the ends and the means. According to the ends, the research will be descriptive and as to the means, the research will be bibliographical, field. The study is indicating as basic, descriptive, with a quantitative approach, it ran from January 2018 to December of the same year. Field research took place in November 2018 and was conducted with 10 university students of the administration course, who are attending the 8th semester. For the data collection, a structured questionnaire was used with closed questions, based on the Lickert scale, later on the tabulation of the data. In the analysis, it was noticed how much the course of administration has been growing in the country, as well as the multiple interests that correlate to the choice of administration course, as well as wage pretension, development of the entrepreneurial career and the importance of the course for local development.

Keywords: Professional Expectations. Perspectives. Management course.

Resumo: Este artigo tem por objetivo analisar as premissas, perspectivas e expectativas profissionais de alunos que ingressam no curso de Administração. Para tanto, foram elencados os seguintes objetivos específicos: caracterizar o público investigado quanto alguns aspectos sociais e econômicos; identificar as principais justificações que influenciaram na escolha do curso de Administração e analisar as perspectivas e expectativas com relação à escolha do mesmo. A pesquisa de campo ocorreu no mês de novembro de 2018 e foi conduzida junto a 10 universitários do curso de administração, os quais estão cursando o $8^{\circ}$ semestre. Para a coleta de dados foi utilizado um questionário estruturado com questões fechadas, baseando-se na escala Lickert, posteriormente ocorreu a tabulação dos dados. Ao realizar a análise percebeu-se o quanto o curso de administração vem crescendo no país, bem como os múltiplos interesses que correlaciona-se para a escolha do curso de administração, bem como pretensão salarial, desenvolvimento da carreira empreendedora e a importância do curso para o fomento local.

Palavras-chave: Expectativas profissionais. Perspectivas. Curso de administração.

${ }^{1}$ Bachelor's Degree Student in Management at the Dom José Institute and Education and Culture (IDJ), Brazil. Email: dayannedibel@gmail.com.

${ }^{2}$ Professor at Dom José Institute and Education and Culture (IDJ), Brazil. Email: admfelipe.neris@gmail.com

${ }^{3}$ Professor at Dom José Institute and Education and Culture (IDJ), Brazil. 


\section{Introduction}

In the past years, Management education has been going through a process of expansion of higher education courses, a fact that shows the increase in the number of students. This growth is due to an expansion of higher education in the country. However, there was a greater growth in Management courses. This course is molded from its generalization of areas of knowledge, enabling practical experience during the course, thus developing a multidisciplinary profile that provides personal maturity and professional identity, necessary tools to act in unpredictable situations, a reality that are subject to current organizations.

Given the dissolute scenario in the labor market and the existence of increased competition for opportunities, professionals are faced with the urgency of a solid career. They seek to improve their skills, abilities, attitudes and/or knowledge. In this context, Management courses arise that have been disseminated in an accelerated way over the years, and it is one of the courses that most trains people in the whole of Brazil, as it has a diverse range of specializations, bringing these professionals together in the various segments of the field of role of the manager.

From this perspective, the following starting questions arise: what are the assumptions that influence admission to the Management course? What are the perspectives and expectations of the students who take part in the Management course? Given the above, this research has the general objective: to analyze the premises, perspectives and professional expectations of students entering the Management course. And its specific objectives are to characterize the investigated public regarding some social and economic aspects; identify the main reasons that influenced the choice of the course and analyze the perspectives and expectations regarding the choice of it.

The relevance of this study is based on highlighting the reasons, expectations, and perspectives of the students in relation to the choice of the Management course, class 2015, at the State University Vale do Acaraú - UVA / Dom José Institute - IDJ, in order to know what they think like future managers, what will be their professional contributions to the labor market, and thus explore the nuances that foster the theme. The study will also seek to provide organizations with a survey 
that can be used later as an aid tool for those seeking to improve their internal qualification programs, regarding the benefits offered by an undergraduate degree. It is also highlighted, as a reference for the business community, that they are interested in improving their practices and their collaborative body. Thus, the present work is also contributing to the researcher, both in a personal, professional, and academic scope, as well as with regard to the scientific community through the research results.

In terms of structure, the research initially presents the introduction, followed by the theoretical foundation, which addresses administration and its theoretical evolution, the concepts that discuss this science, as well as the manager professional and the job market for the Management, exposing the strengths and the points for improvement. Subsequently, the methodology is discussed, expressing the development of the research, ending with an appreciation of the collected data and considerations about them.

\section{The Management Course: Concepts, Fundamentals and Historical Evolution}

According to Martins (2018), Management education in Brazil is directly related to its development, being divided into two significant historical moments, the first marked by the Vargas government, approaching a representative character with a nationalist project, and the second based on the Kubitschek government, characterized by the developmental project, linked to the opening of the economy, which evidenced the industrialization process. In this context, in the mid1960s, with the expansion of economic development, higher education courses were strongly promoted, especially Management, due to the demand for qualified labor.

For Lisbon (2016), the profession of manager, in Brazil, was created from Law No. 4,769, of September 9, 1965, being later regulated by Decree 61,934, of February 24, 1966. In 2009, the registration was approved. professional in the respective regional councils, through a Normative Resolution of the Federal Management Council, made official and recognized by the Ministry of Education. The purpose of these courses is to train professionals with skills and abilities to work in competitive and changing markets, aiming to develop technical, practical, and entrepreneurial characteristics in the student. 
Martins (2018) points out that the administration course since 2009 has been standing out due to the number of newcomers, being also the graduation that most inserted professionals in the labor market. With such expressive data, doubts arise about the aspects that the professional manager goes through during training, to establish himself as to the demands of the labor market.

Lisboa (2016) states that the exercise of the profession of managers is based on the historical principles of the work of Taylor, Fayol and their followers. The deepening of studies generates several moments that gave rise to the Schools of Management and that defined administrative functions - planning, organizing, directing and controlling. Which are currently in force. Corroborating the above, Chiavenato (2016, p. 9) highlights that "Administration is the process of planning, organizing, directing and controlling the use of resources and organizational skills, efficiently and effectively".

In this perspective, Lisbon (2016) also highlights that the proposal for the Administration course is intended to train professionals with skills and abilities to operate in competitive and dynamic markets. During the training, the aim is for the student to develop techniques, experienced practices, flexibility, in addition to developing the student's entrepreneurial spirit. Therefore, skills are present in the areas of management as necessary tools for the development of leaders, associated with the capabilities needed for the decision-making process. Managerial skills are present in organizations providing services and producing goods.

Vanin and Silva (2010) state that the beginning of the 20th century is characterized by the great growth and development of companies, however managers started to use the strategy more actively in the middle of the second half of the same century. It was decided to join an administration with a more strategic vision due to the need for the right directions to be able to expand the business. The aforementioned authors point out that the organization's strategy aims at a direction for the future, it is to plan in a calculated way where one intends to arrive and the risks arising from the actions performed.

In this perspective Chiavenato (2016) states that the word administration came from Latin and means the function by which it is performed under the command of others, in contemporaneity administration is the way in which a variety of resources is used. Within the complexity that involves administration and 
the figure of the administrator, this macro function can be divided into smaller functions, such as: marketing, finance, human resources, logistics, and so on. Over time, the concept of administration has been improved and continues to evolve, as new types of demand and needs arise.

Martins (2018) points out that every training process has a guiding curricular base, administration in turn is characterized as a complex and challenging human science and is based on training principles correlated to the socio-economic context, focusing on primarily to the needs of organizations. Regarding the aforementioned author, Chiavenato (2016) highlights that administration is the scope through which organizations are maintained and developed to achieve efficiency and effectiveness in their operations and actions, aiming to obtain competitiveness and grandiose results. Management is the way things happen in organizations.

Chiavenato (2016) emphasizes that administration represents contemporaneity, it is the representation of our lives and the work we do. The world is surrounded by companies of varying sizes, people are inside and outside organizations, both working on them and depending on them. However, such organizations need to be managed, given that they do not stand alone.

\section{The Manager Professional}

Within each organization there is a driving force, which is not always perceived in many companies, a fact that makes this tool little used, not giving the result of productivity that every organization aspires to. Such strength, when idealized within organizations, helps to achieve success, the result of a synchronized work of an engaged team, recognized and valued for its merits and its importance, where, once these aspirations are satisfied, they identify with the objective of company.

Martins (2018) highlights that professional training is characterized by a process in which the individual goes through to build, in a structured way, his/her conceptual basis, the usual practices and future professional experiences. The author elucidates that, in view of market demands, having a well-founded professional training will place her in a prominent position. 
Lisboa (2016) emphasizes the development of skills necessary for the administrator, which is evident according to article 3 of the decree that regulates the profession (61.934/67):

The professional activity of the Administrator, as a profession, liberal or not, comprises: elaboration of opinions, reports, plans, projects, arbitrations and reports, in which the application of knowledge inherent to the organization techniques was required; research, studies, analysis, interpretation, planning, implementation, coordination and control of work in the fields of general administration, such as personnel administration and selection, organization, analysis, work methods and programs, budget, material and financial administration, marketing administration , production administration, industrial relations, as well as other fields in which these unfold or with which they are connected. (CRA-SP. Regional Administration Council of São Paulo).

Chiavenato (2016) highlights that the role of the administrator is to direct companies, lead them to gain advantages that can leverage their competitiveness and sustainability over time. Strategy is a way in which managers organize their resources with the aim of maximizing organizational results. Currently, a notorious challenge for manager professionals is to ensure a competitive advantage in relation to the market in which they operate, given that the external environment directly impacts the company's activities,

According to the author, he also highlights that the administrator needs to have some mechanisms to produce effective results for the organization, such as:

\begin{tabular}{|l|l|}
\hline Knowledge & Understand, diagnose, how and what should be done. \\
\hline Skills & Know how to perform tasks, through your work team. \\
\hline Judgment & $\begin{array}{l}\text { Identify and know how to decide, about what should be done, decide the goals } \\
\text { to be executed. }\end{array}$ \\
\hline Attitude & Being innovative, entrepreneurial, always seeking change and transformation \\
\hline
\end{tabular}

Souce: Chiavenato (2016)

Martins (2018) emphasizes that the skills necessary for the good performance of the administrative function must be developed throughout professional training, and such skills may change due to external interference.

To Chiavenato, the role of the administrator in the modern world "is becoming more and more important, necessary and indispensable. It constitutes the essential fulcrum for the success of organizations. All require the role of the 
administrator for success and perpetuity and for collective well-being". (CHIAVENATO, 2016, p. 12).

For the Federal Management Council (CFA) and the Regional and Management Council (CRA) (2015), the manager needs to develop a broad vision of the organization, have leadership, motivation, know how to work in a team, be resolute, strategist, hold a managerial position and guided by ethics. In a study carried out by Martins (2018) it is clear that for manager professionals to stand out in relation to their competitors and to remain in the labor market is essential for the development of skills and competences, with a view to meeting complex demands, the need for adequate training is also exposed.

\section{The Labor Market for the Manager}

Bock (2013) highlights that to analyze the labor market for the administrative public, the areas that are most prominent are consulting, influenced by the high rate of medium and small-sized companies; the service sector; direct and indirect public administration and the industrial sector.

Within this prism Silva, Oliveira and Oliveira (2015) point out that with globalization and technological advances the world has been undergoing significant changes, consequently such changes affect the labor market, making it more demanding in terms of hiring new employees. There was a change in the values which were attributed to machines and equipment, being today passed to intangible means, such as knowledge. With such variants, the difficulty of inserting young administrators into the labor market is perceived.

For Silva, Oliveira and Oliveira (2015), the labor market is defined as an instrument of supply and demand, which is constituted by companies and the opportunities that emanate from them. It is also understood as the process of attracting people to a given position. In this context, corroborating the ideas presented, Chiavenato (2009) discusses that the market is a type of meeting of job offers, offered by different organizations, with a workforce that demand employment. In this sense, market is understood as an exchange that aims to meet the needs of both sides. 
In a study carried out by Silva, Oliveira and Oliveira (2015), it is noted that the most significant difficulties for young people to enter the labor market are: professional experience, lack of qualifications and low remuneration for the vacancies offered.

Silva, Oliveira and Oliveira (2015) highlight that the world has been undergoing constant adaptations in the development of the labor market, in all areas. Globalization and technological advances make the market more rigorous in terms of hiring new professionals. Thus, it is noted that values that were previously attributed to machines and equipment are now found in intangible means such as knowledge and specializations.

The Federal Administration Council (CFA) (2018) in partnership with the Administration Institute Foundation (FIA) released the current profile of business administrators, through a national survey on the administrator's profile, education, performance, and job opportunities. Highlighting the growing female participation in the profession, as well as the index of opportunities generated by the private sector (58\%), focusing on the following areas: services in general; industry; retail business; business consulting; financial institutions and hospital and health services.

Silva, Oliveira, and Oliveira (2015) say that there are several reasons that make it difficult for young administrators to enter the labor market, most of the young graduates spend about fifteen months to get a job, according to data provided by the United Nations. (UN). The number of university graduates exceeds the availability of adequate work for that level.

Adverse to the authors, data collected by the G1 portal (2018) indicates that according to a survey carried out by the Ministry of Labor, manager professionals are among the most sought after by companies in Brazil in the first four months of 2018. About 12,441 are admitted, professionals in the field, registered, placing their career in fifth place among the most requested. The manager can work in several segments and in several organizations, with possibilities in the national and international market. With a dense and comprehensive training, it has as its main challenges increasing productivity and maximizing results in the public or private sphere, acting in an innovative way through the use of technologies aimed at managing and developing solutions for new demands. 
Silva, Oliveira and Oliveira (2015) emphasize that modern professionals need to develop technical skills to perform their tasks. However, technical knowledge alone does not guarantee a prominent position, it is necessary to develop behavioral skills. For Rabaglio (2008), competences can be defined as a set of knowledge, skills and attitudes that make it specific and allow the individual to perform, with effectiveness and efficiency, certain activities, in any situation, in a peculiar way.

Through a study carried out by Silva, Oliveira and Oliveira (2015), it was noticed that, in the interviewees' evaluations, the main difficulties of young people when entering the labor market are related to: professional experience, lack of qualification and low remuneration of the vacancies offered. Note that lack of experience comes first in terms of difficulty. Thus, this management system harms newly graduated candidates who have little experience, given the opportunities that arise. Therefore, we place the responsibility on companies to be flexible.

\section{The Management Course at Instituto Dom José - IDJ / Vale Do Acaraú State University - UVA}

The Management Course at the State University of Vale do Acaraú already complies with Resolution No. 04/2005 of the National Council of Education (CNE), which established the National Curriculum Guidelines for the Undergraduate Course in Administration, where the main purpose of the course is to teach higher education, professional and technical in Administration, graduating bachelors, for the exercise of the profession throughout the country, conducting research and extension in various fields of culture that subsidize professional performance.

Its area of expertise is diversified, where it can act in the areas of: Financial Administration, Marketing Administration/Marketing; Administration and Person Selection; Information Systems Administration and Foreign Trade. Aiming to train entrepreneurs and responsible professionals, where they can have a broader vision, develop specific knowledge in the area of administration, a citizen awareness and ethics committed to social responsibility and sustainable development in the region. 
The UVA Management Course is based on its objectives and its curricular structure, seeking to train professionals whose profile is:

- Humanistic training and a global vision that enables them to understand the social, political, economic and cultural environment in which they are inserted and to make decisions, in an effective way, in a complexly diversified and interdependent world;

- Technical and scientific training to work in the Administration of organizations in general, in addition to developing specific professional practice activities that are oriented to the regional reality.

The State University of Vale do Acaraú-UVA in the interior, more specifically in the municipality of Jaguaribe, has as a partner in the delivery of higher education courses, among which the Dom José Institute - IDJ is the Management course.

The Dom José Institute of Education and Culture - IDJ created on June 7, 2002, has the social objective of contributing to the improvement of educational, cultural, scientific and technological communications. Promotes the democratization of higher education with decentralized courses. It ensures broad access to all and contributes to the harmonious spread of knowledge and the integral development of society. It develops education as the main basis for local growth and for valuing the population's potential.

The Dom José Institute coordinates courses at the University of Vale do Acaraú - UVA, working in Fortaleza and in several municipalities in the interior of Ceará, always concerned with the quality and qualification of its employees, and its faculty and students, invests in the realization of studies and research to ensure respect for diversity, based on serious work, and trust placed in each partner who together make up the Institute.

\section{Methodology}

The present study was carried out in the city of Jaguaribe - CE, at the Dom José Institute of Education and Culture (IDJ), with the students of the Administration course, who are attending the 8th semester. The research classification is presented in two aspects: regarding the ends and regarding the means. According to 
the purposes, the research will be descriptive, because it aims to describe the perceptions of university students in relation to the administration course, the reason for choosing the course, in addition to other aspects related to the development of the course during the four years of study.

As for the means, the research will be bibliographical, in the field. Bibliographic in the literature review phase, aiming to provide a theoretical framework on the Management course and the labor market. In the field, due to data collection, with the class of the 8th semester of the course.

The study is characterized as basic, descriptive, with a quantitative approach. According to Cervo et al (2007), basic or pure research aims to satisfy intellectual needs through knowledge. For Gil (2014), descriptive research aims to describe the particularities of a group or determine relationships between variables. The quantitative method describes a quantity approach, it is a means of testing objective theories, it examines the relationship between variables in a population or a sample thereof, where numerical data are analyzed by statistical procedures (CRESWELL, 2010).

The study took place from January 2018 to December of that year, where it comprised the development of three distinct moments. Starting with a bibliographical survey, enunciating the main concepts and fundamentals about the theme, seeking to elucidate the nuances that involve it. This focused on searching sites for scientific journals in the area, as well as books.

The second involved field research, marked by the application of a structured questionnaire in closed questions, considering the proposed objectives. In the questionnaire, the Lickert scale was adopted as a data verification parameter. The Lickert scale, according to Marconi and Lakatos (2010, p. 109) provides "the elaboration of a large number of proportions considered important in relation to attitudes or opinions, which have a direct or indirect relationship with the objective to be studied". Within this prism, it is also highlighted that this research aims to ensure the confidentiality of information provided by the researched public as well as the location where the field research was carried out. Having used the Informed Consent Form (FICF). 
The questionnaire according to Gil (2014) is a technique used to get to know the research participants and their particularities. The questionnaire was applied to students during the month of November 2018.

The third moment was characterized by the tabulation of collected data and final writing of the article. In order to make the tabulation process feasible, the Microsoft Excel program, version 2013 was used.

\section{Data Analysis}

Table 01: characterization of the subjects, regarding social and economic aspects

\begin{tabular}{|l|l|r|}
\hline Indicators & Parameters & $\begin{array}{c}\text { Fr } \\
\text { (\%) }\end{array}$ \\
\hline Gender & Male & 70 \\
\hline & Feminine & 30 \\
\hline \multirow{2}{*}{ Where did you attend high school? } & from 20 to 30 & 70 \\
\hline & from 31 to 40 & 10 \\
\hline Income & $>40$ & 20 \\
\hline & Public school & 60 \\
\hline Has worked or works in the administrative area & Private school & 30 \\
\hline & scholarship holder & 10 \\
\hline & From 0 to 1 salary & 40 \\
\hline & 2 to 3 salaries & 40 \\
\hline This is your first graduation? & $>3$ salaries & 20 \\
\hline & Not & 70 \\
\hline
\end{tabular}

Total Searched: 10

Table 01 analyzes the public in terms of social and economic aspects and characteristics. The first poll deals with the gender of the respondents, where there is a large representation of the male audience, representing $70 \%$ of the same, within this prism, there is great significance of this audience, whereas the female audience represents $30 \%$ of those investigated. Another highlight is inferred in the second 
survey, where there is a supremacy in the ages of 20 to 30 years, which is satisfactory, given the importance for local development in the search for broader knowledge, thus contemplating society as a all, such representation is $70 \%$. It should be noted that from 31 to 40 years old, it presented $10 \%$, as well as those over 40 years old with $20 \%$.

Regarding the period of high school, $60 \%$ of respondents claimed to have attended a public school, followed by $30 \%$ who studied in the private network and $10 \%$ who were scholarship holders in private schools. Regarding the average salary, the items corresponding to 0 to 1 salary and 2 to 3 salaries, obtained a percentage of $40 \%$ and $40 \%$ respectively, while respondents who receive more than three salaries are equivalent to $20 \%$, such analysis goes to meeting with the results observed in polls 14 , where $50 \%$ fully agree with the assertion that the choice of the Management course was also due to the search for increased remuneration.

Survey 05 , in turn, considers those who have or have already had experience with the administrative area, where $70 \%$ of respondents said they have already worked in the respective area, which makes the analysis satisfactory, given the need for balance between theory and the practice. It is also found that this is the first undergraduate course held by $100 \%$ of the class.

Table 02: Identify the main justifications that influenced the choice of the administration course

\begin{tabular}{cll}
\hline Survey & Parameters & Fr\% \\
$\begin{array}{c}\text { Was the course chosen } \\
\text { due to family influence? }\end{array}$ & I totally agree & 70 \\
& partially agree & 30 \\
\hline I totally disagree & - \\
\hline I partially disagree & - \\
$\begin{array}{c}\text { Was the choice of the } \\
\text { course due to the } \\
\text { influence of friends? }\end{array}$ & I totally agree & - \\
\hline $\begin{array}{c}\text { Was the choice of the } \\
\text { due to the }\end{array}$ & I totally agree & 30 \\
\hline $\begin{array}{c}\text { course } \\
\text { influence of teachers or }\end{array}$ & partially agree & 10 \\
\hline
\end{tabular}




\begin{tabular}{|c|c|c|}
\hline \multirow[t]{3}{*}{ the school? } & I totally disagree & 50 \\
\hline & I partially disagree & 40 \\
\hline & undecided & - \\
\hline \multirow{5}{*}{$\begin{array}{l}\text { Was the choice of the } \\
\text { course due to } \\
\text { employment opportunities } \\
\text { in the area? }\end{array}$} & I totally agree & 10 \\
\hline & partially agree & 70 \\
\hline & I totally disagree & 20 \\
\hline & I partially disagree & - \\
\hline & undecided & - \\
\hline \multirow{5}{*}{$\begin{array}{l}\text { Was the course chosen } \\
\text { due to its identification } \\
\text { with the area? }\end{array}$} & I totally agree & 20 \\
\hline & partially agree & 60 \\
\hline & I totally disagree & 20 \\
\hline & I partially disagree & - \\
\hline & undecided & - \\
\hline \multirow{5}{*}{$\begin{array}{l}\text { Was the choice of the } \\
\text { course due to the ease of } \\
\text { holding public tenders? }\end{array}$} & I totally agree & 30 \\
\hline & partially agree & 70 \\
\hline & I totally disagree & - \\
\hline & I partially disagree & - \\
\hline & undecided & - \\
\hline
\end{tabular}

Table 02 seeks to identify respondents regarding the choice of the Management course. In this aspect, 70\% highlighted that the family expresses a significant influence on their academic life. With regard to friends, there is a nonsense, as $30 \%$ believe that they were fundamental in their decisions to attend administration, however $40 \%$ partially disagree with such an assertion, when performing a joint analysis of the parameters I totally disagree and partially disagree, the same have a $50 \%$ highlight.

The following survey highlights the influence of teachers in the stimulus process, regarding the inclusion of respondents in higher education courses, noting that the highest representation is in the parameter I totally disagree with $50 \%$, followed by the parameter I partially disagree with $40 \%$, to analyzing them together, it is noticed the supremacy that they represent, which means that teachers were not decisive instruments in the process of entering higher education for those investigated. 
However, when the choice of the Management course is correlated with the job market, it is noted that this parameter influences the choice of profession, where $80 \%$ totally and partially agree, showing significance. It is noteworthy that identification with the field of study also characterizes course choice $80 \%$ agree fully and partially.

Regarding the facilities for public examination, $70 \%$ partially agree and $30 \%$ fully agree, characterizing the administrative area as an excellent opportunity in the public and private sphere, offering multiple benefits for professionals.

Table 03: Analyze perspectives and expectations regarding the choice of the course

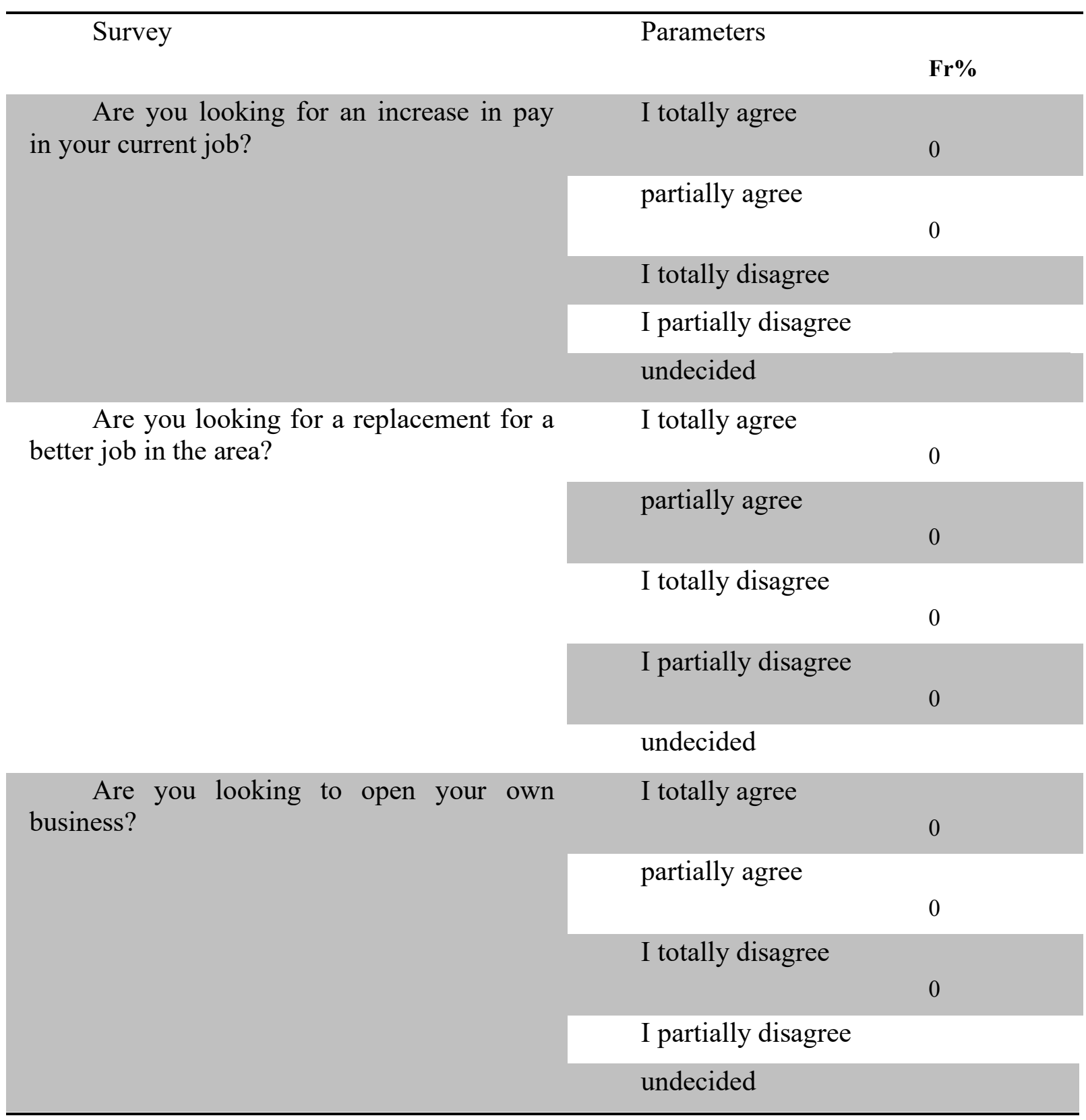


Table 03 analyzes the perspectives and expectations regarding the choice of the Management course. Regarding the increase in remuneration in the current job, 50\% partially agree, being tied with 50\% that fully agree; therefore, these two parameters have total supremacy. The following poll, which emphasizes the change of job to work directly in the administrative area, $70 \%$ totally agree.

When asked about their performance in an entrepreneurial way, starting their own business $50 \%$ totally agree, followed by $40 \%$ who partially agree, it is worth noting that $10 \%$ totally disagree. Such an analysis is significant, as local entrepreneurship fosters development.

\section{Final Considerations}

This research sought to verify the premises, perspectives and professional expectations of students entering the Management course. The objectives suggested in the research were achieved, with regard to the external influence that the student had to enter the higher education course, specifically in the administrative area, noting that family, friends and employment opportunities both in the private sphere, as in the public sector, they form the perception of those investigated for investiture in the Management course. Such parameters make the analysis satisfactory, thus showing itself to be relevant to the literature presented.

Regarding the perspectives and expectations in relation to the course, there is a scope aimed at professional relocation, they seek such relocation in order to obtain greater economic advantages. There is also an interest in undertaking and promoting the region, seeking improvements not only for the professional, but for those who make up the local society as a whole.

It is noteworthy that the survey cannot be generalized to all students in business courses, since its sampling was based on ten students, so the authors suggest further research with greater depth and with a larger audience.

It is essential, therefore, that there is research in the local area with a view to finding entrepreneurial opportunities. This research suggests, given the reality 
presented, that feasibility studies (business plan) be developed for those who wish to implement a business

\section{References}

Bock, Hugo. (2013). Professional Perspectives of Students I attend business as a second degree. Available at: Access at:

Deer, Beloved Luiz. (2007). Scientific methodology / Amado Luiz Cervo, Pedro Alcino Bervian, Roberto da Silva. - 6. ed. - São Paulo: Pearson Prentice Hall.

Chiavenato, Idalbert. (2016). Fundamentals of Administration: planning, organization, direction and control to increase sustainability and control. Rio de Janeiro. Elsevier.

Chiavenato, Idalbert. (2009). Human Resources. 9. Ed. Rio de Janeiro: Elsevier, 2009.

CRA-SP. São Paulo Regional Board of Directors. Available on: accessed 23/08/2015. Available at: <http://www.crasp.gov.br/crasp>. Accessed on: May 14, 2018.

Crewell, John w. (2010). Research project: qualitative, quantitative and mixed method. 3. Ed. Porto Alegre: Artmed.

Gil, Antonio Carlos. (2014). Methods and techniques of social research. 6. Ed. -6. Reprint - São Paulo: Atlas.

Dom José Institute of Education and Culture (IDJ). Who we are: history. Available at: $<$ https://www.idj.com.br/instituton>. Accessed on: 13. Sep.2018. Law 4769, of September 9, 1965. Provides for the exercise of the profession of administrator. Brasília 1965. Available at: <http://www.cfa.org.br>. Accessed on: Oct. 18, 2017.

Lisbon, Teresinha Covas. (2016). The formation of the administrator in Brazil: competences and abilities. Available at: <http://www.aforges.org/wpcontent/uploads/2016/11/38-Teresinha-Covas-Lisboa_A-formacao-do-administradorno-Brasil.pdf $>$. Accessed on: Jun. 27, 2018

Marconi, Marina de Andrade; Lakatos, Eva Maria. (2010). Research techniques: planning and carrying out research, sampling and research techniques, elaboration, analysis and interpretation of data. 7. Ed. - 3. Reprint. - São Paulo: Atlas.

Martins, Maria Estelha de Melo. (2018). Identification of significant factors in the professional training of students in the management course at UEPB Campus I. Available at: PortalG1. Available at: https://g1.globo.com/ce/ceara/especialpublicitario/unifor/ensinando-e-aprendendo/noticia/mesmo-em-cenario-de-crisemercado-de-trabalho-para-administrador -opera-in-expansion.ghtml. Accessed on: 02 Jan. 2018. 
Rabaglio, M.O. (2008). Competency-focused performance assessment tools. Rio de Janeiro: Qualit Mark.

Silva, Annyelle Magda Souza da; Oliveira, Mayara Evelin Soares de; Oliveira, Rita Patrícia Almeida de. (2015). Young administrators and the job market. Graduation notebooks: human and social sciences. ISSN 2316-3143. V.2, n.1, p. 39 - 52. Available at: <http://www.priodicos.set.edu.br>. Accessed on: June 01, 2018. University Vale do Acaraú (UVA) Who we are: history. Available at: < http://www.uvanet.br/>. Accessed on: 13.Sep.2018.

Vanin, Jorge Alexandre; Silva, Paula Maines da. (2010). Competitive strategy and corporate marketing: differences and similarities. GES - Management and Society Magazine. CEPEAD/UFMG vol. 4, $\mathrm{n}^{\circ}$ 7. Available at: <www.ges.face.ufmg.br/>. Accessed on: May 14, 2018.

\section{How to cite this article (APA format):}

NOGUEIRA, L.D.S.; SOUSA, F.N.T. de.; SALDANHA, M.E.S. (2021). Professional Perspectives of the Management Course Students - Class of 2015 of the Vale do Acaraú University - UVA/IDJ. Am. In. Mult. J., Oct. (11) 6, 08-25.

Received: 08/07/2021

Accepted: 10/22/2021

Published: 10/31/2021 